\title{
Serum biochemistry and haematology in wild and captive bearded seals (Erignathus barbatus) from Svalbard, Norway
}

\author{
Morten Tryland ${ }^{1,2^{*}} \mathbb{D}$, Christian Lydersen ${ }^{3}$, Kit Maureen Kovacs ${ }^{3}$, Espen Rafter ${ }^{4}$ and Stein Istre Thoresen ${ }^{5}$
}

\begin{abstract}
Background: Health assessment of seals in captivity include haematology and serum biochemistry measurements. Because such parameters differ between species, it is crucial to have species-specific reference values for the interpretation of clinical samples. Furthermore, differences in nutrition and environment, life cycles as well as seasonal/annual cycles and varying physiological conditions can potentially affect serum chemistry and haematology parameters. Blood samples from four captive adult bearded seals (initially caught as pups in Svalbard, Norway, now held at Polaria, an Arctic experience centre in Troms $\varnothing$, Norway) collected over a 16-month period were analysed for haematology $(n=22)$ and serum chemistry $(n=25)$ parameters. Serum chemistry analyses were also conducted on blood samples from 74 wild bearded seals (1995-2007) collected from Svalbard, Norway.

Results: We found higher activity of creatine kinase (CK) and higher concentrations of cortisol in the wild animals when compared to the captive seals, probably reflecting the physical restraint and concomitant stress induced during sampling. For the captive bearded seals, we did not find marked differences in haematology or serum chemistry parameters throughout the different seasons of sampling.

Conclusions: This study presents haematology and serum chemistry reference values for captive and wild bearded seals. Comparing physiological parameters for captive seals with wild seals indicated that having wild-caught bearded seals under the conditions offered at Polaria for several years did not markedly affect physiological parameters of the animals, and that training may have helped to alleviate stress associated with blood sampling and veterinary inspection.
\end{abstract}

Keywords: Arctic, Clinical pathology, Environmental monitoring, Erignathus barbatus, Haematology, Marine mammal, Pinniped, Seal, Wildlife

\section{Background}

The bearded seal (Erignathus barbatus) is the largest northern phocid seal. This species is distributed, at low densities, throughout the circumpolar Arctic. Adults are $2-2.5 \mathrm{~m}$ long and weigh $250-300 \mathrm{~kg}$ or more. However,

\footnotetext{
*Correspondence: morten.tryland@uit.no

${ }^{1}$ Department of Arctic and Marine Biology, UiT The Arctic University

of Norway, Framstredet 39, 9037 Tromsø, Norway

Full list of author information is available at the end of the article
}

their weight varies quite dramatically on an annual cycle, and females, for example, have been recorded weighing more than $425 \mathrm{~kg}$ in spring [1]. The pups are born on ice floes during the spring, with peak pupping occurring in early May [2]. At birth pups are approximately $1.3 \mathrm{~m}$ long and weigh about $37 \mathrm{~kg}$ [2]. Pups enter the water shortly after being born and can swim and dive down to $200 \mathrm{~m}$ depth prior to weaning; older animals can dive deeper but rarely do because they feed in shallow, shelf waters. The pups stay close to their mothers for 2-3 weeks during the lactation period and weigh around $100 \mathrm{~kg}$ at weaning.

(c) The Author(s) 2021, corrected publication 2021. Open Access This article is licensed under a Creative Commons Attribution 4.0 International License, which permits use, sharing, adaptation, distribution and reproduction in any medium or format, as long as you give appropriate credit to the original author(s) and the source, provide a link to the Creative Commons licence, and indicate if changes were made. The images or other third party material in this article are included in the article's Creative Commons licence, unless indicated otherwise in a credit line to the material. If material is not included in the article's Creative Commons licence and your intended use is not permitted by statutory regulation or exceeds the permitted use, you will need to obtain permission directly from the copyright holder. To view a copy of this licence, visit http://creativecommons.org/licenses/by/4.0/. The Creative Commons Public Domain Dedication waiver (http://creativecommons.org/publicdomain/zero/1.0/) applies to the data made available in this article, unless otherwise stated in a credit line to the data. 
Preferred bearded seal habitat is drifting pack ice in shallow areas over coastal shelves. Bearded seals are found at low densities in the fjords of Svalbard, Norway. They are predominantly benthic feeders, eating clams, shrimp, squid, crabs and fish. A study on stomach contents of bearded seals on Svalbard $(n=47)$ revealed a varied diet, with no significant differences between males and females. Polar cod (Boreogadus saida) was an important prey species that was found in $49 \%$ of the animals, proportionally in terms of frequency of occurrence followed by sculpins (Cottidae spp.; 44\%), long rough dab (Hippoglossoides platessoides; $28 \%$ ) and other fish species. In addition, molluscs (e.g., Buccinum spp.; 18\%) and several other species of invertebrates were found in the stomachs [3]. Bearded seals have a longevity of $20-25$ years in the wild [1].

Polaria is an Arctic experience centre located in Tromsø, Norway, which hosts aquariums with a variety of Arctic species including bearded seals. Seals in captivity are usually housed in an environment that is very different from the one in which they live in the wild. Captive environments often include differences in latitude (light conditions) and climatic conditions, feeding and nutrition, as well as variable possibilities and motivation for physical exercise. All of these parameters are important for the mental and physical health and well-being of an animal. Therefore, animals in captivity are often engaged in training programs to promote physical exercise and mental stimulation. These training programs also offer possibilities to get animals used to handling and to conduct clinical investigations and sampling without the need for anaesthesia. At Polaria, the bearded seals are trained to allow weighing and body condition assessment (palpation), inspection of mucosal membranes (eyes, mouth, nostrils, anus and reproductive organs), inspection of the flippers and the skin as well as biological sampling, such as blood sampling.

Without a proper training program, the possibilities for conducting a thorough clinical examination of captive bearded seals without the use of drugs or extreme restraint, would be impossible. Even if these samples were obtained, the lack of reference values for this species limits clinical interpretation. Therefore, obtaining and reporting haematology and serum chemistry parameters from bearded seals is extremely valuable. The aim of this study was to establish species-specific haematology and serum chemistry reference values for captive adult bearded seals and to provide comparative serum chemistry reference values from wild bearded seals.

\section{Methods}

\section{Animals}

Four bearded seals housed at Polaria, Tromsø, Norway were included in this study. These animals were caught as large pups in Kongsfjorden, Svalbard $\left(78.9^{\circ} \mathrm{N}, 12.3^{\circ} \mathrm{E}\right)$ in 1998 (one male) and 2003 (three females). The seal pool at Polaria is approximately $100 \mathrm{~m}^{2}$ in size with a maximum depth of $4 \mathrm{~m}$. The seals have access to the pool and "land" areas ad libitum. The indoor environment at Polaria is different from the High Arctic environment at Svalbard. However, the facility tries to replicate natural conditions as closely as possible, using, for example, a light regime that mimics the winter and summer season at higher latitudes. The water for the pool is obtained from the marine fjord just outside the facility at $20 \mathrm{~m}$ depth. The water temperature is at a minimum in February $\left(1-2{ }^{\circ} \mathrm{C}\right)$ and at a maximum in August $\left(<10^{\circ} \mathrm{C}\right)$ with some natural annual variation. The animals in this study were fed mainly Norwegian spring-spawning herring (Clupea harengus), sometimes mixed with capelin (Mallotus villosus). The animals were usually fed three times a day, as part of the training regime, as well as the performance and information dissemination programme with visitors to the facility. At the time of blood sampling the males were 8-9 years old and the females were 4-5 years old. A total of 25 blood samples were obtained during different months (February, March, April, May, June, August, November and December) throughout 2006-2008. Blood was sampled without previous fasting but before feeding. Blood was drawn from the plantar venous plexus of the hind flippers using blood collection tubes (full blood tubes for serum and EDTA tubes for plasma; Venoject ${ }^{\circledR}$, Terumo, Leuven, Belgium) and $0.8 \times 40 \mathrm{~mm}$ needles $\left(\right.$ Venoject $\left.{ }^{\circledR}\right)$. Serum was prepared by centrifugation at $3000 \times g$ for $15 \mathrm{~min}$ and kept refrigerated. Full blood and serum were sent for analyses on the day of sampling and analysed the following day (Central Veterinary Laboratory, Norwegian University of Life Sciences) for haematology and serum biochemistry parameters (Table 1).

Wild bearded seals $(n=74)$ were sampled in Kongsfjorden, Svalbard $\left(78.9^{\circ} \mathrm{N}, 12.3^{\circ} \mathrm{E}\right)$ in $1995(\mathrm{n}=13), 2005$ $(\mathrm{n}=10), 2006(\mathrm{n}=17)$ and $2007(\mathrm{n}=34)$. All animals were caught and sampled in the month of May while the pups were still nursing. For these procedures, the animals were physically restrained without using anaesthesia or sedation. The sampled animals included seven adults (all females) and 67 pups ( 22 females, 45 males). The average weight of the pups was $53.8 \mathrm{~kg}$ (range 27-101 kg) and the average weight of adults was $339 \mathrm{~kg}$ (range $237-421 \mathrm{~kg}$ ). Blood was obtained from the extradural intra-vertebral vein using either a $2.1 \times 80 \mathrm{~mm}$ or $2.1 \times 150 \mathrm{~mm}$ needle (depending on the age of the animal) (Sterican ${ }^{\circledR}$, VWR International, Oslo, Norway) mounted on a $50 \mathrm{~mL}$ syringe. The blood was transferred into blood collection tubes (full blood tubes for serum preparation; Venoject $\left.{ }^{\circledR}\right)$ and serum was prepared through centrifugation (as described above). The samples from the wild 
Table 1 Analytical methods used for serum biochemistry analyses of bearded seals (Erignathus barbatus) from Svalbard, Norway

\begin{tabular}{|c|c|c|c|}
\hline Analyte $^{a}$ & Method/principle & Manufacturer ${ }^{\mathbf{b}}$ & References \\
\hline AST & Modified IFCC & Siemens & {$[4]$} \\
\hline ALT & Modified IFCC & Siemens & {$[4]$} \\
\hline ALP & Modified IFCC & Siemens & {$[4]$} \\
\hline CK & $\mathrm{N}$-acetylcysteine act., DGKC & Siemens & {$[4]$} \\
\hline $\mathrm{LDH}$ & Enzymatic/Tris/NAD & Siemens & {$[4]$} \\
\hline Amylase & Ethylidene blocked-pNPG7 & Siemens & {$[4]$} \\
\hline Lipase & Kinetic colorimetric & Sera-Pak & {$[5]$} \\
\hline Albumin & Serum protein electrophoresis & Beckman & - \\
\hline Bilirubin (total) & Diazo/caffeine & Siemens & {$[4]$} \\
\hline Calcium & $C P C$ & Siemens & {$[6]$} \\
\hline Chloride & Ion-selective electrode, diluted & Siemens & {$[4]$} \\
\hline Cholesterol & Enzymatic & Siemens & {$[7]$} \\
\hline Cortisol & Solid-phase, chemiluminescent, competitive immunoassay & DPC & [8] \\
\hline Creatinine & Jaffe, alkaline picrate, kinetic & Siemens & [9] \\
\hline NEFA & ACS-ACOD-MEHA & Wako & [10] \\
\hline Glucose & Hexokinase & Siemens & [11] \\
\hline Magnesium & Xylidyl blue & Siemens & [12] \\
\hline Phosphorus (inorg.) & Phosphomolybdate/ultraviolet & Siemens & [13] \\
\hline Potassium & Ion-selective electrode, diluted & Siemens & {$[4]$} \\
\hline Protein (total) & Biuret & Siemens & [4] \\
\hline Sodium & Ion-selective electrode, diluted & Siemens & {$[4]$} \\
\hline Thyroxine & Solid-phase, chemiluminescent, competitive immunoassay & Siemens & [14] \\
\hline Triglycerides & GPO, trinder without serum blank & Siemens & [15] \\
\hline Urea & Urease with GLDH & Siemens & [16] \\
\hline
\end{tabular}

${ }^{a}$ AST Aspartate aminotransferase, ALT Alanine aminotransferase, ALP Alkaline phosphatase, CK Creatine kinase, LDH Lactate dehydrogenase, NEFA Non-esterified fatty acids

b Siemens Healthcare Diagnostics (including Sera-Pak), Tarrytown, NY, USA; Beckman Coulter, Inc, Fullerton, CA, USA; DPC: Diagnostic Products Corporation, Los Angeles, CA, USA; Wako Chemicals GmbH, Neuss, Germany

C IFCC International Federation of Clinical Chemistry, $p N P G 7$-nitro-phenylmalto-heptaoside, NAC N-acetylcysteine, DGKC Deutsche Gesellschaft für Klinische Chemie, CPC o-cresolphtalein complexone, ACS-ACOD-MEHA Acyl-CoA-Synthetase-Ascorbate oxidase- 3-Methyl- $N$-Ethyl-N-(B-hydroxyethyl)aniline, GPO glycerol-3-phosphate oxidase, GLDH glutamate dehydrogenase

bearded seals were then stored at $-20{ }^{\circ} \mathrm{C}$ until analyses were undertaken in 2008 (Central Veterinary Laboratory, Norwegian University of Life Sciences). Due to the unavoidable delay from sampling of wild animals to analysis, haematological analysis was not possible for samples from wild bearded seals as haematological parameters are not stable and should be analyzed within $24 \mathrm{~h}$.

\section{Haematology analyses}

Haematology parameters were assayed for 22 samples (from the four captive individuals) with an ADVIA $^{\circledR} 2120$ Hematology System using ADVIA 2120 MultiSpecies $^{\text {TM }}$ System Software (Siemens Healthcare Diagnostics, Tarrytown, NY, USA). The reference values for haematology parameters were calculated in Excel and are presented as mean, due to a restricted number of measurements, and standard deviation to indicate the variation.

\section{Serum chemistry and endocrinology analysis}

A total of 25 serum samples from four captive bearded seals and serum samples from 74 wild bearded seals were analysed for selected enzymes, proteins, metabolites, minerals, cortisol, and thyroxine (Table 1). Serum chemistry analyses were assayed using an ADVIA $^{\circledR}$ 1650 System (Siemens Healthcare Diagnostics, USA). Lipaemia was indicated by the ADVIA 1650 System, and samples classified as lipaemic $(1+$ and $2+)$ were automatically diluted before analysis to avoid erroneous measurements [17]. Serum endocrinology analyses (cortisol and thyroxine) were assayed using an IMMULITE $^{\circledR} 2000$ Immunoassay System (Siemens Healthcare Diagnostics, USA). The reference values for serum biochemistry parameters and hormones were calculated in Excel and are presented as median, range (min-max) and percentiles (5-95\%), to show variation and a reference range that is excluding outliers. 


\section{Results}

Haematology results (captive seals only) are presented in Table 2 for each individual $(\mathrm{n}=4)$ and for all samples $(\mathrm{n}=22)$ combined. Serum biochemistry parameters for wild bearded seals (pups and adults) and captive adult bearded seals are presented in Table 3.

From the wild bearded seals, 36 samples were classified by the ADVIA system as being slightly lipaemic $(1+)$ and 28 were classified as moderately lipaemic $(2+)$. When comparing results from samples with no or slight lipaemia $(1+)$ to samples with moderate lipaemia $(2+)$, we found no obvious differences for parameters previously reported for marine mammal sera that might potentially be affected by moderate lipaemia, such as creatine kinase (CK), alkaline phosphatase (ALP), lactate dehydrogenase (LDH), lipase, urea, creatinine, sodium and chloride [18]. No lipaemia was recorded for the serum samples obtained from the captive bearded seals.

Serum activity of CK was higher in wild pups (mean $622 \mathrm{U} / \mathrm{L}, S D$ 684, range 114-3383 U/L) than in wild adults (mean $389 \mathrm{U} / \mathrm{L}, S D$ 488, range 55-1239 $\mathrm{U} / \mathrm{L}$ ) and captive adults (mean $172 \mathrm{U} / \mathrm{L}, S D$ 84, range 89-458 U/L). Cortisol concentration was higher in wild adults (mean $956 \mathrm{nmol} / \mathrm{L}, S D$ 193, range 612$1206 \mathrm{nmol} / \mathrm{L}$ ) than in wild pups (mean $437 \mathrm{nmol} / \mathrm{L}, S D$ 189 , range $199-977 \mathrm{nmol} / \mathrm{L}$ ) or in captive adults (mean $352 \mathrm{nmol} / \mathrm{L}, S D 74$, range $236-549 \mathrm{nmol} / \mathrm{L}$ ).

\section{Discussion}

We present herein the first thorough set of haematology and serum biochemistry reference values for captive (adult) bearded seals and serum biochemistry reference values for wild (adult and pup) bearded seals. These reference values may be valuable tools for assessing health status for this species, especially for bearded seals in captivity.

Haematology data on bearded seals is in general very limited; however, two studies report haematology parameters from wild bearded seals from the Chukchi Sea and Bering Sea $[19,20]$. Compared to the values reported in these studies, the values for haematocrit (HCT), haemoglobin (Hb/HGB), and mean corpuscular haemoglobin concentration $(\mathrm{MCHC})$ for the four captive adult bearded seals in our study were within the same range. It should be noted, in any case, that the studies of the Chukchi Sea and Bering Sea bearded seals were, similar to our study, based on only a few individuals (one adult, six subadults and one pup).

The total globulin concentrations were higher in wild adult bearded seals compared to wild pups, and higher in adult wild bearded seals compared to captive adults. In particular, the concentrations of the gamma globulins were higher in wild adults compared to both captive adults and wild pups. The reasons for this are not obvious, but it could be hypothesised that the immune system of wild adults might be exposed to more challenges, provoking infections and inflammation resulting in

Table 2 Haematology parameters for four captive bearded seals (Erignathus barbatus) over a period of 19 months (2006-2008), presented as mean (standard deviation) for each individual and combined

\begin{tabular}{|c|c|c|c|c|c|}
\hline \multirow[t]{2}{*}{ Parameter $^{a}$} & \multicolumn{4}{|c|}{ Individual seals ${ }^{\mathbf{b}}$ (number of samples from each seal) } & \multirow{2}{*}{$\begin{array}{l}\text { All samples } \\
\text { combined } \\
(n=22)\end{array}$} \\
\hline & $\begin{array}{l}\text { "Diesel" o } \\
(n=2)\end{array}$ & "Aurora"ㅇ $(n=6)$ & "Maisan" $ᄋ(n=7)$ & "Bella" $\odot(n=7)$ & \\
\hline WBC $\left(10^{9} / L\right)$ & 9.5 & $11.6(2.4)$ & $7.4(0.8)$ & $9.5(2.6)$ & $9.5(1.2)$ \\
\hline $\mathrm{RBC}\left(10^{12} / \mathrm{L}\right)$ & 3.8 & $4.0(0.3)$ & $3.7(0.1)$ & $3.8(0.2)$ & $3.8(0.1)$ \\
\hline $\mathrm{HGB}(\mathrm{g} / \mathrm{L})$ & 217 & $211(24)$ & $231(12)$ & $230(16)$ & $217(20)$ \\
\hline $\mathrm{HCT}(\mathrm{L} / \mathrm{L})$ & 0.45 & $0.51(0.04)$ & $0.54(0.02)$ & $0.54(0.02)$ & $0.50(0.10)$ \\
\hline$M C V(f L)$ & 122 & $128(15)$ & $146(5)$ & $142(7)$ & $135(13)$ \\
\hline $\mathrm{MCHC}(\mathrm{g} / \mathrm{L})$ & 435 & $414(28)$ & $429(11)$ & $430(31)$ & $427(3)$ \\
\hline RDW (\%) & 16.8 & $16.8(4.7)$ & $12(0.7)$ & $13.5(2.1)$ & $14.8(2.5)$ \\
\hline $\operatorname{PLT}\left(10^{9} / \mathrm{L}\right)$ & 220 & $305(59)$ & $224(132)$ & $216(76)$ & $241(4)$ \\
\hline Neutrophils $\left(10^{9} / \mathrm{L}\right)$ & 5.1 & $6.7(1.2)$ & $4.7(0.5)$ & $5.6(0.4)$ & $5.5(0.4)$ \\
\hline Lymphocytes $\left(10^{9} / \mathrm{L}\right)$ & 2.5 & $2.6(0.6)$ & $1.6(0.3)$ & $2.5(2.3)$ & $2.3(0.5)$ \\
\hline Monocytes $\left(10^{9} / \mathrm{L}\right)$ & 0.9 & $1.2(0.4)$ & $0.7(0.1)$ & $1.0(0.3)$ & $1.0(0.1)$ \\
\hline Eosinophils $\left(10^{9} / \mathrm{L}\right)$ & 0.8 & $1.0(0.6)$ & $0.3(0.2)$ & $0.3(0.2)$ & $0.6(0.3)$ \\
\hline Basophils $\left(10^{9} / \mathrm{L}\right)$ & 0.3 & $0.1(0.1)$ & $0.0(0.0)$ & $0.1(0.1)$ & $0.1(0.1)$ \\
\hline
\end{tabular}

${ }^{a}$ WBC white blood cell count, $R B C$ red blood cell count, $H G B$ hemoglobin, $H C T$ hematocrit, $M C V$ mean corpuscular volume, $M C H C$ mean corpuscular hemoglobin concentration, $R D W$ red cell distribution width, PLT platelet count

b "Diesel" was 8-9 years old and "Aurora”," Maisan" and "Bella” were 4-5 years old at the time of sampling. "Diesel" was sampled only twice and results are presented as mean, not including standard deviation 
Table 3 Clinical serum biochemistry parameters for wild (Svalbard, Norway) and captive bearded seals (Erignathus barbatus), presented as median, range and 5-95 percentiles

\begin{tabular}{|c|c|c|c|c|c|c|c|c|c|c|c|c|}
\hline \multirow[t]{2}{*}{ Analyte $^{a}$} & \multicolumn{4}{|c|}{ Pups (wild) } & \multicolumn{4}{|c|}{ Adults (wild) } & \multicolumn{4}{|c|}{ Adults (captive) } \\
\hline & $\mathrm{n}^{\mathrm{b}}$ & Median & Range & $5-95 \%$ & $\mathbf{N}$ & Median & Range & $5-95 \%$ & $\mathrm{~N}$ & Median & Range & $5-95 \%$ \\
\hline AST (U/L) & 67 & 79 & 49-198 & $53-148$ & 7 & 46 & 39-106 & $39-96$ & 25 & 58 & $35-89$ & $37-84$ \\
\hline $\operatorname{ALT}(\mathrm{U} / \mathrm{L})$ & 67 & 8 & $0-24$ & $1-16.4$ & 7 & 5 & $1-33$ & $1.3-27.6$ & 25 & 41 & $28-60$ & $33-59$ \\
\hline ALP (U/L) & 67 & 556 & $232-961$ & $299-868$ & 7 & 56 & $14-110$ & $15-102$ & 25 & 123 & $6-260$ & $27-196$ \\
\hline CK (U/L) & 67 & 385 & $114-3383$ & $136-2346$ & 7 & 126 & $55-1234$ & $56-1147$ & 25 & 150 & $89-458$ & $97-286$ \\
\hline LDH (U/L) & 67 & 669 & 271-1897 & $329-1175$ & 7 & 185 & $89-1245$ & $97-1028$ & 25 & 354 & $201-965$ & $254-812$ \\
\hline Amylase (U/L) & 67 & 1 & $0-9$ & $0-5$ & 7 & 1 & $0-6$ & $0.3-4.8$ & 23 & 1 & $0-4$ & $0-2$ \\
\hline Lipase (U/L) & 67 & 25 & $11-54$ & $14-47$ & 7 & 142 & $52-156$ & $62-156$ & 25 & 241 & 69-331 & $124-297$ \\
\hline Protein, total (g/L) & 67 & 59 & $49-69$ & $53-65$ & 7 & 69 & $64-83$ & $64-80$ & 25 & 63 & $55-75$ & $57-72$ \\
\hline Albumin (g/L) & 34 & 40.5 & $31.0-48.6$ & $32.6-44.2$ & 5 & 36.5 & $35.6-41.9$ & $35.6-41.5$ & 25 & 35 & $29-38$ & $32-38$ \\
\hline Globulin total (g/L) & 34 & 19 & $14-26$ & $15-22$ & 5 & 33 & $28-41$ & $29-40$ & 25 & 29 & $25-39$ & $25-34$ \\
\hline a1-globulins (g/L) & 34 & 3.9 & $2.9-5.4$ & $3.2-4.9$ & 5 & 4.4 & $4.3-5.1$ & $4.3-5.0$ & 25 & 5 & $3-9$ & $3.3-8.5$ \\
\hline a2-globulins (g/L) & 34 & 4.7 & $3.2-7.4$ & $3.5-6.7$ & 5 & 7.5 & $6.6-7.8$ & $6.6-7.8$ & 25 & 10 & $6-13$ & $6.7-12.9$ \\
\hline$\beta$-globulins $(\beta 1+\beta 2 ; g / L)$ & 34 & 7.9 & $5.9-11.8$ & $6.1-9.5$ & 5 & 13.8 & $10.4-16.4$ & $10.4-16.7$ & 25 & 8 & $6-13$ & $6.7-10.9$ \\
\hline Y-globulins (g/L) & 34 & 2 & $0.6-4.8$ & $0.7-4.4$ & 5 & 7.5 & $6.7-12.5$ & $6.8-12.1$ & 25 & 6 & $3-9$ & $3.2-8.2$ \\
\hline Total bilirubin ( $\mu \mathrm{mol} / \mathrm{L})$ & 67 & 1 & $0-11$ & $0-7.4$ & 7 & 1 & $1-4$ & $1-3.4$ & 25 & 1 & $0-6$ & $1-3.6$ \\
\hline Urea $(\mathrm{mmol} / \mathrm{L})$ & 67 & 9.8 & $4.5-19.0$ & $6.6-16.2$ & 7 & 8.2 & $6.3-9.3$ & $6.4-9.1$ & 25 & 6 & $4-10$ & $4.5-8.8$ \\
\hline Creatinine $(\mu \mathrm{mol} / \mathrm{L})$ & 67 & 119 & $77-362$ & $92-180$ & 7 & 173 & $153-213$ & $155-209$ & 25 & 139 & 110-194 & $118-158$ \\
\hline Cholesterol (mmol/L) & 67 & 6 & $1.9-10$ & $3.0-9.0$ & 7 & 3 & $2.6-5.7$ & $2.6-5.4$ & 25 & 5 & $4-7$ & $3.9-6.9$ \\
\hline NEFA (mmol/L) & 67 & 1.2 & $0.3-3.2$ & $0.5-2.3$ & 7 & 1 & $0.3-1.4$ & $0.5-1.4$ & 25 & 0 & $0-1$ & $0.02-0.56$ \\
\hline Glucose (mmol/L) & 67 & 6.8 & $1-13.4$ & $3.3-10.6$ & 7 & 6.6 & $1.2-12.2$ & $2.5-11.1$ & 25 & 6 & $3-8$ & $3.1-7.2$ \\
\hline Calcium (mmol/L) & 67 & 2.6 & $1.1-3.0$ & $2.4-2.9$ & 7 & 1.9 & $1.2-2.5$ & $1.3-2.5$ & 25 & 2 & $2-3$ & $2.1-2.5$ \\
\hline Phosphate (inorg.; mmol/L) & 67 & 3 & $1.5-5.6$ & $2.0-4.1$ & 7 & 2.3 & $0.7-3.6$ & $0.9-3.5$ & 25 & 2 & $2-3$ & $1.5-2.3$ \\
\hline Magnesium (mmol/L) & 67 & 1.1 & $0.7-2.1$ & $0.9-1.7$ & 7 & 1 & $0.8-1.3$ & $0.8-1.3$ & 25 & 1 & $1-1$ & $0.9-1.2$ \\
\hline Sodium (mmol/L) & 67 & 153 & $131-159$ & $146-157$ & 7 & 153 & $149-166$ & $149-164$ & 23 & 153 & $150-160$ & $151-157$ \\
\hline Potassium (mmol/L) & 67 & 4.1 & $3.1-5.9$ & $3.5-4.6$ & 7 & 4.1 & $3.7-4.7$ & $3.7-4.6$ & 23 & 4 & $4-5$ & $3.7-4.9$ \\
\hline Chloride (mmol/L) & 67 & 102 & $86-107$ & $97-107$ & 7 & 106 & $102-108$ & $103-108$ & 23 & 114 & $107-117$ & $110-116$ \\
\hline Total T4 (nmol/L) & 67 & 49 & $11-151$ & $23-118$ & 7 & 25 & $13-29$ & $14.2-28.1$ & 21 & 23 & $9-74$ & $10-62$ \\
\hline Cortisol (nmol/L) & 67 & 398 & 199-977 & $212-832$ & 7 & 1010 & $612-1206$ & $674-1162$ & 21 & 345 & $236-549$ & $265-491$ \\
\hline
\end{tabular}

${ }^{a}$ AST Aspartate aminotransferase, ALT Alanine aminotransferase, ALP Alkaline phosphatase, CK Creatine kinase, LDH Lactate dehydrogenase, NEFA Non-esterified fatty acids

${ }^{b} \mathrm{n}$ indicates the number of animals that were sampled and analyzed for each specific analyte. For captive adult bearded seals, the data is based on blood samples obtained from four 9-10-year-old bearded seals sampled 2-7 times each (2006-2008)

increased serum concentrations of gamma globulins. The lower gamma globulin levels in pups might reflect their immature immune system.

From the serum biochemistry analyses, it was clear that the ALP activity was higher in the serum from wild pups, as compared to both wild and captive adult seals. This is in line with findings from White Sea bearded seals (E. $b$. barbatus). Animals that were 3-5 years old had higher levels of ALP compared to animals that were ten years of age [21]. The limited sample size in that (and our) study limits interpretation of these results, although higher ALP activity in younger individuals is a well-known finding in other seal species (e.g., hooded seals; Cystophora cristata) and harp seals (Phoca groenlandica) [22], as well as in humans [23]. As the pups in our study were quite young, a few days to 2-3 weeks, ALP results should be interpreted with these age effects in mind.

The serum CK activity was highest in wild pups, followed by wild adults and lowest in captive adults. Creatine kinase is found in tissues that consume adenosine-triphosphate (ATP) rapidly, such as muscle tissue. Creatine kinase activity in serum is used as a marker of muscle disease or trauma [24-26]. In addition, in several seal species, higher concentrations of this enzyme have been found in muscle tissue compared to other body tissues [24], and high CK activity in serum has been associated with handling stress in harbor seals (Phoca vitulina) [27]. Thus, the higher CK activity found in wild bearded 
seal adults and pups, compared to captive individuals, may reflect the stress and physical activity associated with netting and restraint of the animals during sampling. This suggestion is also supported by the serum cortisol levels, which were highest in wild adults, followed by wild pups, and lowest in captive animals. Glucocorticoids (corticosterone and cortisol) are mediators of the physiological stress response in mammals. Although cortisol in blood serum has been extensively used as a stress marker, care should be taken when interpreting its values. Cortisol is released in response to a stressor almost immediately, causing spikes in the blood cortisol concentrations; therefore, one should be aware that, particularly in wild animals, cortisol concentrations may be affected by the stress induced even by the blood sampling itself [28]. Still, it is notable that in our study both the CK levels and cortisol levels were lower for the captive bearded seals. Although this comparison is based on few individuals, these results support the benefit of training captive animals to cooperate during veterinary investigations and sampling to reduce stress responses.

Seasonal variations of several physiological parameters may be observed in wild populations due to seasonal changes in environmental conditions. However, we did not find any indications of seasonal differences for the captive bearded seals of this study; suggesting that these animals might have a steady physiological state throughout the year.

\section{Conclusions}

The results of this study represent haematology and serum chemistry reference values for captive bearded seals and serum chemistry reference values for wild bearded seals. The values for both groups were similar for most parameters suggesting that holding wild-caught bearded seals at Polaria for several years has not altered the animals' serum chemistry parameters substantially from what is normal for wild animals. Furthermore, it appears that Polaria's training regime has largely alleviated stress associated with blood sampling and general veterinary inspection.

\section{Acknowledgements}

We thank Børre With and Eirik Mack Eilertsen at Polaria for the collaboration during sampling of the captive bearded seals, and all the people who participated in the various fieldwork periods with bearded seals over the years. We also thank Dr Andrea Miller for a critical review of the manuscript.

\section{Prior publication}

A subset of the serum chemistry data was included in a table on bearded seal reference values, presented as an appendix to a book chapter in: Gulland FMD, Dierauf LA, Whitman KL. (Eds.), Handbook of Marine Mammal Medicine, 3rd edition, ISBN 9781498796873, CRC Press 2018

\section{Authors' contributions}

MT and SIT planned the study. CL and KMK conducted sampling of wild animals. MT, ER and SIT conducted sampling of captive animals. SIT conducted the haematology and serum chemistry analyses, and MT and SIT evaluated the results. MT wrote the first draft of the manuscript. All authors provided editorial inputs. All authors read and approved the final manuscript.

\section{Funding}

The field programme was financed by the Norwegian Research Council MARE (grant number 164940 to KMK) and the Norwegian Polar Institute. The publication charges for this article have been funded by a grant from the publication fund of UiT The Arctic University of Norway.

\section{Availability of data and materials}

The datasets used and/or analyzed during the current study are available from the corresponding author upon request.

\section{Declarations}

\section{Ethics approval and consent to participate}

The animals were handled according to high ethical standards and national legislation. Permits for catching and sampling wild bearded seals were given by Forsøksdyrutvalget (the Research Animal Authority), Norway, FDU permit 2005/2953.

\section{Consent for publication}

Not applicable.

\section{Competing interests}

The authors declare that they have no competing interests.

\section{Author details}

${ }^{1}$ Department of Arctic and Marine Biology, UiT The Arctic University of Norway, Framstredet 39, 9037 Troms $\varnothing$, Norway. ${ }^{2}$ Department of Forestry and Wildlife Management, Inland Norway University of Applied Sciences, 2480 Koppang, Norway. ${ }^{3}$ Norwegian Polar Institute, Fram Centre, 9296 Troms $\varnothing$, Norway. ${ }^{4}$ Polaria, Hjalmar Johansens gate 12, 2007 Troms $\varnothing$, Norway. ${ }^{5}$ Faculty of Veterinary Medicine, Norwegian University of Life Sciences, 1432 Ås, Norway.

Received: 6 December 2020 Accepted: 18 August 2021

Published online: 26 August 2021

\section{References}

1. Kovacs KM. Bearded seal Erignathus barbatus. In: Würsig B, Thewissen JGM, Kovacs KM, editors. Encyclopedia of marine mammals. New York: Academic Press; 2018. p. 83-6.

2. Kovacs KM, Krafft BA, Lydersen C. Bearded seal (Erignathus barbatus) birth mass and pup growth in periods with contrasting ice conditions in Svalbard, Norway. Mar Mammal Sci. 2020;36:276-84.

3. Hjelset A, Andersen M, Gjertz I, Lydersen C, Gulliksen B. Feeding habits of bearded seals (Erignathus barbatus) from the Svalbard area, Norway. Polar Biol. 1999;21:186-93. https://doi.org/10.1007/s003000050351.

4. Tietz NW. Clinical guide to laboratory tests. 3rd ed. Philadelphia: W. B. Saunders Co.; 1995. p. 611.

5. Fossati P, Ponti M, Paris P, Berti G, Tarenghi G. Kinetic colorimetric assay of lipase in serum. Clin Chem. 1992:38:211-5.

6. Gitelman HJ. An improved procedure for the determination of calcium in biochemical specimens. Anal Biochem. 1967;18:521-31.

7. Richmond W. Preparation and properties of a cholesterol oxidase from Nocardia sp. and its application to the enzymatic assay of total cholesterol in serum. Clin Chem. 1973;19:1350-6.

8. Farmer R, Pierce C. Plasma cortisol determinations: radioimmunoassay and competitive protein binding compared. Clin Chem. 1974;20:411-4.

9. Jaffe MZ. Ueber den Niederschlag, welchen Pikrinsaure in normalem Harn erzeugt and ueber eine Reaktion des Kreatinins. Z Physiol Chem. 1886;10:391-400.

10. Duncombe WG. The colorimetric micro-determination of non-esterified fatty acids in plasma. Clin Chim Acta. 1964;10:122-5.

11. Slein MW. Methods of enzymatic analysis. In: Bergmeyer HU, editor. New York: Academic Press Inc; 1974. p. 1196-201. 
12. Mann CK, Yoe JH. Spectrophotometric determination of magnesium with sodium 1-azo-2-hydroxy-3-(2,4 dimethylcarboxanilido)-naphtalene-1'-(2hydroxybenzene). Anal Chem. 1956;16:155-60.

13. Daly JA, Ertinghausen G. Direct method for determining inorganic phosphate in serum with the centrifichem. Clin Chem. 1972;18:263-5.

14. Jandresksi MA. Chemiluminescence technology in immunoassays. Lab Med. 1998;29:555-60.

15. Fossati P, Prencipe L. Serum triglycerides determined colorimetrically with an enzyme that produces hydrogen peroxide. Clin Chem. 1982;28:2077-80.

16. Roch-Ramel F. An enzymatic and fluorophotometric method for estimating urea concentrations in nanoliter specimens. Anal Biochem. 1967;21:372-81.

17. Bayer ADVIA 1650 Chemistry System (Bayer Corporation, Tarrytown, NY, USA). System software version 3.31E. Online operator guide version 4.00.00.

18. Tryland M, Brun E. Serum chemistry of the minke whale from the northeastern Atlantic. J Wildl Dis. 2001;37:332-41.

19. Bossart GD, Reidarson TH, Dierauf LA, Duffield DA. Clinical pathology. In: Dierauf LA, Gulland FMD, editors. CRC handbook of marine mammal medicine. 2nd ed. Boca Raton: CRC Press; 2001. p. 383-436.

20. Goertz CEC, Reichmuth C, Thometz NM, Ziehl H, Boveng P. Comparative health assessments of Alaskan ice seals. Front Vet Sci. 2019. https://doi. org/10.3389/fvets.2019.00004.

21. Erokhina IA, Kavtsevich NN. Blood plasma chemistry in White Sea bearded seals across different age groups. Arct Environ Res. 2019;19:15965. https://doi.org/10.3897/issn2541-8416.2019.19.4.159.
22. Boily F, Beaudoin S, Measures LN. Hematology and serum chemistry of harp (Phoca groenlandica) and hooded seals (Cystophora cristata) during the breeding season, in the Gulf of St. Lawrence, Canada. J Wildl Dis. 2006;42:115-32. https://doi.org/10.7589/0090-3558-42.1.115.

23. Zierk J, Arzideh F, Haeckel R, Cario H, Frühwald MC, Groß HJ, et al. Pediatric reference intervals for alkaline phosphatase. Clin Chem Lab Med. 2017;55:102-10. https://doi.org/10.1515/cclm-2016-0318 (PMID: 27505090).

24. Fauquier DA, Mazet JAK, Gulland FMD, Spraker TR, Christopher MM. Distribution of tissue enzymes in three species of pinnipeds. Zoo Wildl Med. 2008;39:1-5.

25. Duncan JR, Prasse KW, Mahaffey EA. Veterinary laboratory medicine. Ames: lowa State University Press; 1994. p. 300.

26. Moghadam-Kia S, Oddis CV, Aggarwal R. Approach to asymptomatic creatine kinase elevation. Clevel Clin J Med. 2016;83:37-42.

27. Staubín DJ, Austin TP, Geraci JR. Effects of handling stress on plasma enzymes in harp seals, Phoca groenlandica. J Wildl Dis. 1979;15:569-72.

28. Palme R. Non-invasive measurement of glucocorticoids: advances and problems. Physiol Behav. 2019;199:229-43.

\section{Publisher's Note}

Springer Nature remains neutral with regard to jurisdictional claims in published maps and institutional affiliations.
Ready to submit your research? Choose BMC and benefit from:

- fast, convenient online submission

- thorough peer review by experienced researchers in your field

- rapid publication on acceptance

- support for research data, including large and complex data types

- gold Open Access which fosters wider collaboration and increased citations

- maximum visibility for your research: over $100 \mathrm{M}$ website views per year

At BMC, research is always in progress.

Learn more biomedcentral.com/submissions 